\title{
Camel Research of Selected Pharmaceutical Industries
}

\author{
Shipra Gupta, Vijay Kumar, Jasmeet Kalra
}

\begin{abstract}
The pharmaceutical industry is observed to have an unhampered growth and is anticipated to grow supplemental a compound annual growth rate (CAGR) of 3-6\% over the next five years. The worldwide expenditure on medicines has crossed US $\$ 1.2$ Trillion in 2018 and is expected to go over US \$1.5 Trillion by 2023. The new product lift-offs, particularly the specialty range have been the major contributor in the growth accomplishment. However, reforming per capita income, accelerating consciousness towards health, geriatric population, elevated chronic ailments along with technological magnifications are significantly pitching towards the growth accomplishment. The following economies have majorly pitched in towards the pharmaceuticals expenditure in 2018: US (US \$ 486 Billion), top five European markets (US \$178 Billion), China (US \$ 137 Billion), Japan (US \$ 86 Billion).Looking at the trend it seems that the growth of the world-wide pharmaceutical expenditure will majorly be moved by developed economies through innovatory products created using latest technology. United States appears to remain a fairy godmother in the pharmaceutical industry. However, emerging economies like Brazil, India, Russia (Tier 2 markets) and Tier 3 markets shall also confer to the growth process. Their CAGR is projected to grow 5-8\% through 2023 to reach US \$ 355 - 385 Billion.
\end{abstract}

Key Words: Pharmaceutical Industries, capital adequacy, asset quality, management efficiency, earning quality, liquidity position, ratios, performance

\section{INTRODUCTION}

GlaxoSmithKline Pharmaceuticals Limited (GSK) is a multinational pharmaceutical company started its operations in 1715 with apharmaciststore in London. GSK has consistentlyintent on novelty design and have endlesslyevolved with range of medicines and wellness and healthcare products. This is a world-wide healthcare company with the specific purpose: to assist public act more, feel healthier, survive longer. This company has three worldwide businesses to facilitate research, expand and produce novel pharmaceutical medicines, vaccines and customer healthcare and wellness items.

Pfizer Inc. the parent company of Pfizer limited, is in American multinational pharmaceutical corporation with its headquartered in New York City established in 1849, based in New York City .

Revised Manuscript Received on November 25, 2019.

Shipra Gupta, Assistant Professor, Department of Commerce, Graphic Era Hill University, Uttarakhand, India.

Vijay Kumar, Professor, Department of Physics, Graphic Era Hill University, Uttarakhand, India.

Jasmeet Kalra, Assistant Professor, Department of Mechanical Engineering, Graphic Era Hill University, Uttarakhand, India.
Pfizer limited began its operation in India in 1950, and today it is the third largest pharmaceutical multinational company within the country.

Lupin Limited started with the manufacturing offolic acid and iron tablets for Indian Government well known healthcare program for mother and child andnow it has grown to be the $8^{\text {th }}$ largest generic pharmaceutical company by revenue worldwide with majoremphasis on pediatrics, cardiovascular, anti-infectious, diabetology, asthma and anti-tuberculosis.

In India, Lupin has twelve manufacturing plants along with two research plants. Lupin primarily concentrates on Lifestyle and Chronic disease therapy segment. It has reached 70 countries which include USA, Japan, Mexico and European and South African countries as well.

Cipla Limited is an Indian multinational pharmaceutical and biotechnology company, with its headquarter in Mumbai, India. Itmajorlyproducesmedicines to treat pulmonary, cardio-vascular disease, arthritis, diabetes, obsession and depression. Its founders Khwaja Abdul Hamied initiated it as 'The Chemical, Industrial \&Pharmaceutical Laboratories'. The title of the organisation was changed to 'Cipla Limited' on 20 July 1984. The world's $1^{\text {st }}$ oral iron chelator was launched by, Ciplaas Deferiprone in 1995. In 2001, Cipla startedproducing medicines (antiretroviral) for HIV treatment at a very less cost (much cheaper than $\$ 350$ per year per patient).

\section{I) DEFINING THE PROBLEM}

A comparative study of selected pharmaceutical industry performances by CAMEL approach.

II) OBJECTIVES

- To analyze the monetary execution of selected pharmaceutical industry by the CAMEL approach.

- Ranking of different parameters under CAMEL approach.

\section{REVIEW OF LITERATURE}

Pharmaceutical industries play an important role to improve wealth and health of any country. According to Sudesh Kumar, Bimal Kumar and Suman Nayyar (2012), they have selected four most popular pharmaceutical companies. They have studied about the financial position trend analysis by the help of financial data.FarukHossanand Md Ahsan Habib (2010), have defined the financing performance of two pharmaceutical companiesby ratio analysisin Bangladesh. As per Joseph Golec\& John A. Vernon (2009), they are studied about the comparative study between biotech and pharmaceutical industries in the US about various financial factors, risk and government regulations.Adam Licurse, Emma Barber, Steve Joffe

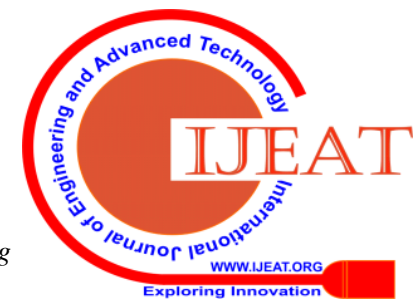




\section{Camel Research of Selected Pharmaceutical Industries}

and Cary Gross (2010) reviewed about impact of financial ties (FTs) to pharmaceutical and medical device companies. As per David M. Studdert, Michelle M. Mello and Troyen A. Brennan. (2004) checked about the regulation of Financial associated between physicians and pharmaceutical industry by the centralized government and qualified organizations.Bharathi Kamath,G. (2008) studied about value added by intelecual capital of twenty five top drugs and pharmaceutical industries. Pal, K. and Soriya, S. (2012) compared between the performance of intellectual capital of textile and pharmaceutical industry. As per Misra and Aspal (2013) have studied about the financial performance of State bank's group by the use of ANOVA and CAMEL tools. According to Rohit Bansal and Anoop Mohanty (2013), to know about the financial performance of commercial banks, they have taken five commercial banks and studied as per CAMEL model.As per CAMEL model Gupta (2014) also workedto find thepublic sector bank's performance.By the application of CAMEL approach Golam Mohiuddin(2014) evaluated that the provided financial services by some commercial banks are satisfactory or not in Bangladesh.Singh (2015) analyzedthe composite profitability of four selected private sector banks.To measure about the performance of these banks different profitability ratios are calculated and ANOVA tool technique is applied.Garg and Kumari(2015) examined the different parameters of profitability for five major private sector banks for ten years by using ratio analysis and ANOVA technique.Hare Krishna Karri, Kishore Meghani\& Bharti Meghani Mishra (2015) compared the studyof financial performance between bank of Baroda and Punjab national bank. By the use of CAMEL model, WACC and analysis by regression,Jaspreet Kaur, Manpreet Kaur and Dr. Simranjit Singh (2015)have surveyed about the performance of five public sector banks.Meena (2016) has found the weakest area of private and public sector banks is NPA and how this can be managed. By the use of this model, Jagjeet Kaur, Dr. Harsh Vineet Kaur (2016) studied thatBank of Baroda is in first position then other public sector banks.Mohammad Kamrul Ahsan (2016) has worked on three Islamic banks of Bangladesh by the help of this model he found the best performer bank.Fivepublic sector banks have been selected to analyse the financial performace by Ajit Kumar (2017) and Muralidhara P. and Chokka Lingam (2017)fordifferent time period.Kajal Kiran (2018)measures the financial health of top seven public sector banks and four private sector banks from 2013-2017 by using CAMEL Analysis.There are various ratios are used for analyze in a better way.S.Panboli and Kiran Birda(2019) analyzed the different ratios of five public and five private sector banks were rankedby CAMEL approach.A study of NandhiniMuniappan (2019) has observed about the behavior, consistency and soundness of six public sector banks by this approach.

\section{RESEARCH METHODOLOGY}

DATA SOURCE: A secondary data source has used for this study. This data is taken from the different websites of different pharmaceutical industry, annual reports, news papers and various journals and research papers. There are three top pharmaceutical industries have taken for thisstudy. STUDY PERIOD: The study (analysis) period is five yearfrom (2014-15) to (2018-19).

SAMPLING: Fundamental process and analysis of these top three pharmaceutical industrieswere examined in different factors of ratios and rating scale in CAMEL approach.

RESEARCH TECHNIQUE: There is a different parameter used of different ratios for measuring the financial performance of different industries and ranked them by likert's rating scale1 strongest to 5 weakest. These parameters are as follows:

C-CAPITAL ADEQUACY RATIO- ANALYZE: This type of ratio is a financial key indicator of an industry. It describes the adequacy or soundness of capital to bear unexpected losses.This is very helpful for indication of overall fiscalposition of the pharmaceutical, to fulfill the additional capital requirement of the management, protecting the depositors, safer side from the bankruptcy and also to support the efficiency and stability of the industries in globe. Capital adequacy of the industries can be analyzed by using following ratios:

A) DEBT-EQUITY RATIO: It shows that for every rupee of equity invested how much the company has borrowed. This is important for Pharmaceutical industries because of the instability of sales, which is caused by the government regulations, and a high debt means a high fixed cost for the company irrespective of its earnings. Low ratio prefers rank 1 .

*Total Debt to Total Equity ratio= Total Liabilities x100/Shareholders' equity

B) TOTAL ADVANCES TO TOTAL ASSETS RATIO: To know about the creditworthiness of pharmaceutical industries this ratio is very helpful. Receivables are including in advance. Re-valued assets are not considered in total assets. In this ratio high ratio prefers rank 1.

$*$ Advance to total assets ratio $=\underline{\text { Advance }} \times 100$

Total Assets

C) EQUITIES TO TOTAL ASSETS RATIO: To know about the levered position of the industries this ratio is very helpful.Where mostlyindustry's assets are their owned, the Industry is less levered. But if it is highly levered, it means most of the industry's assets are by loan or outsources. Highest ratio is preferred as rank 1 .

*Equity/Total Assets ratio= Net Worth x100/Total Assets

\section{A- ASSET QUALITY-ASSESS}

This type of ratio is useful to know thecredit risk assessment of industry. This belongs to a specific asset. By the use of following ratio, industries asset worthiness can be identified:

A) TOTAL EARNING ASSETS TO TOTAL ASSETS RATIO: This ratio implies that the industries method for utilizing all of its total assets effectively in investments or not. A low ratio may indicate that assets are not properly utilized. It is also known as total investment to total assets ratio. Highest proportion prefers rank 1 . 
* Total Earning Assets to total Assets ratio= Total Earning Assets x 100/Total Assets

M- MANAGEMENT EFFICIENCY -EVALUATED: This ratio is used to evaluate the quality of better management to take right decisions onrighttime. This ratio is used to evaluate by the following ratios:

A) RETURN ON ASSETS: The return on total asset depicts about how utilizing the assets in a efficient manner and monetizing it. This ratio shows the industries incomebeside its total assets. This is also identified as Return on investment (ROI). Highest the ratio prefers as rank 1.

$*$ Return on Assets $(\mathrm{ROA})=$ Net income x100/Total Assets

B) RETURN ON EQUITY: This ratio measures that how much a company has gained over the shareholder's wealth. Return on equity can be seen to increase if there is an increase in equity. Highest the ratio prefers rank 1.

*Return on Equity $(\mathrm{ROE})=$ Net Income x100/Shareholders' wealth

E- EARNINGS QUALITY- DETERMINATION THE EARNINGS QUALITY OF SELECTED INDUSTRY: This ratio shows the profitability or earning of the pharmaceutical. Following ratio represents the profitability of the industry:

A) RETURN ON INVESTED CAPITAL: This ratio is very helpful to find out the generated profit after paying tax by the use of industries assets. The highest ratio is preferred and ranked as 1 , which shows that the utilization of Return on invested capital ratio gives an idea as how a well company is using its total capital, which includes its equity and borrowings. Return on invested capital, which includes liability and equity, how well the company has utilized its invested capital the assets is in optimum level.

*Return on Invested capital/Capital employed (after tax) = Net operating profit after tax x100/Invested capital

L- LIQUIDITY POSITION- IDENTIFIES THE LIQUID POSITION: This ratio represents the ability to fulfill their short term obligations of industries. Too low liquidity shows the incapability of industries to meet its short term financial obligation. Too high liquidity indicates that industries are not proper using of cash and by this manner profitability gets blockage. So to maintain the high profit as well as liquidity, a proper equilibrium is necessary. There are some ratios are taken for identified the liquid position of the industries. These are given as the following follows:

A) HIGHLY LIQUID ASSETS TO TOTAL ASSETS RATIO: All the current assets except than stock and prepaid expenses are known as liquid assets. To know about the liquid position of the industries, this ratio is helpful. Higher the ratio gets rank 1 .

*Highly Liquid Assets to total Assets Ratio = Liquid Assets x100/Total Assets

B) CURRENT RATIO: Short term obligations paying ability is represents by current ratio. If this ratio is getting rating one or less than one then it indicates the steady nature of the industries. Two and three rating shows the average and 4 and 5 represents below average performance.

*Current Ratio $=$ Current Assets/Current Liabilities

C) BALANCE AT BANK \& RBI TO TOTAL ASSETS RATIO: Cash in hand and atbanks, short call bills and commercial papers etc are highly liquid assets. This ratio is very helpful to know about the highly liquidity position of any industry. The highestratio is preferred as rank 1 .

*Balance at bank \& RBI to Total Assets = Cash \& Cash equivalent $\mathrm{x} 100 /$ Total Assets

D) CASH RATIO: For the obligation of short term payments to know about the cash position of the industry this ratio is useful. Highest ratio is prefers as rank 1.

* Cash Ratio = Cash and Cash Equivalent x100/Current Liabilities

E) DAYS CASH ON HAND RATIO: To know about the cash position on daily basis, this ratio is beneficial.This is also known as cash cycle.Cash cycle of a company shows how efficient a company is in converting its investment in raw materials into cash. From the fig 2.6 we can see that the cash cycle of the company has been increasing over the year mainly due to increase in debtor collection days which states how many days are required to recover the cash from the debtors while the creditor turnover and the inventory turnover has been constant over the year. It shows an increased efficiency in cash recovery of the company and the decrease in the required cash reserve of the company. A high ratio is preferred as rank 1.

* Days Cash on hand = Cash and Cash Equivalent/(Cash Expenses/365)

\section{DATA ANALYSIS AND ITS INTERPRETATION}

Table 1: Different Ratios Underneath Of C-Capital Adequacy Factor

\begin{tabular}{|c|c|c|c|c|c|c|c|c|}
\hline $\begin{array}{l}\text { Pharmac } \\
\text { eutical } \\
\text { Industry } \\
\text { Name }\end{array}$ & \multicolumn{2}{|c|}{$\begin{array}{l}\text { Avera } \\
\text { ge } \\
\& \\
\text { Rank } \\
\text { to } \\
\text { D/E } \\
\text { Ratio }\end{array}$} & \multicolumn{2}{|c|}{$\begin{array}{l}\text { Avera } \\
\text { ge \& } \\
\text { Rank } \\
\text { to } \\
\text { Advan } \\
\text { ce to } \\
\text { total } \\
\text { Assets } \\
\text { Ratio }\end{array}$} & \multicolumn{2}{|c|}{$\begin{array}{l}\text { Averag } \\
\text { e } \\
\& \text { Rank } \\
\text { to } \\
\text { Equity } \\
\text { to total } \\
\text { Assets } \\
\text { Ratio }\end{array}$} & $\begin{array}{l}\text { Aver } \\
\text { age } \\
\text { Gro } \\
\text { up }\end{array}$ & $\begin{array}{l}\text { Gr } \\
\text { oup } \\
\mathrm{Ra} \\
\mathrm{nk}\end{array}$ \\
\hline DRL & 21 & 2 & 0.6 & 3 & $\begin{array}{l}63 . \\
856\end{array}$ & 2 & 2.33 & 2 \\
\hline Pfizer & $\begin{array}{l}2 . \\
8\end{array}$ & 1 & $\begin{array}{l}2.0 \\
92\end{array}$ & 2 & $\begin{array}{l}74 . \\
714\end{array}$ & 1 & 1.33 & 1 \\
\hline $\begin{array}{l}\text { Sun } \\
\text { pharmac } \\
\text { eutical }\end{array}$ & $\begin{array}{c}37 \\
.8\end{array}$ & 3 & $\begin{array}{l}4.8 \\
14\end{array}$ & 1 & $\begin{array}{l}62 . \\
082\end{array}$ & 3 & 2.33 & 2 \\
\hline
\end{tabular}




\section{Camel Research of Selected Pharmaceutical Industries}

120

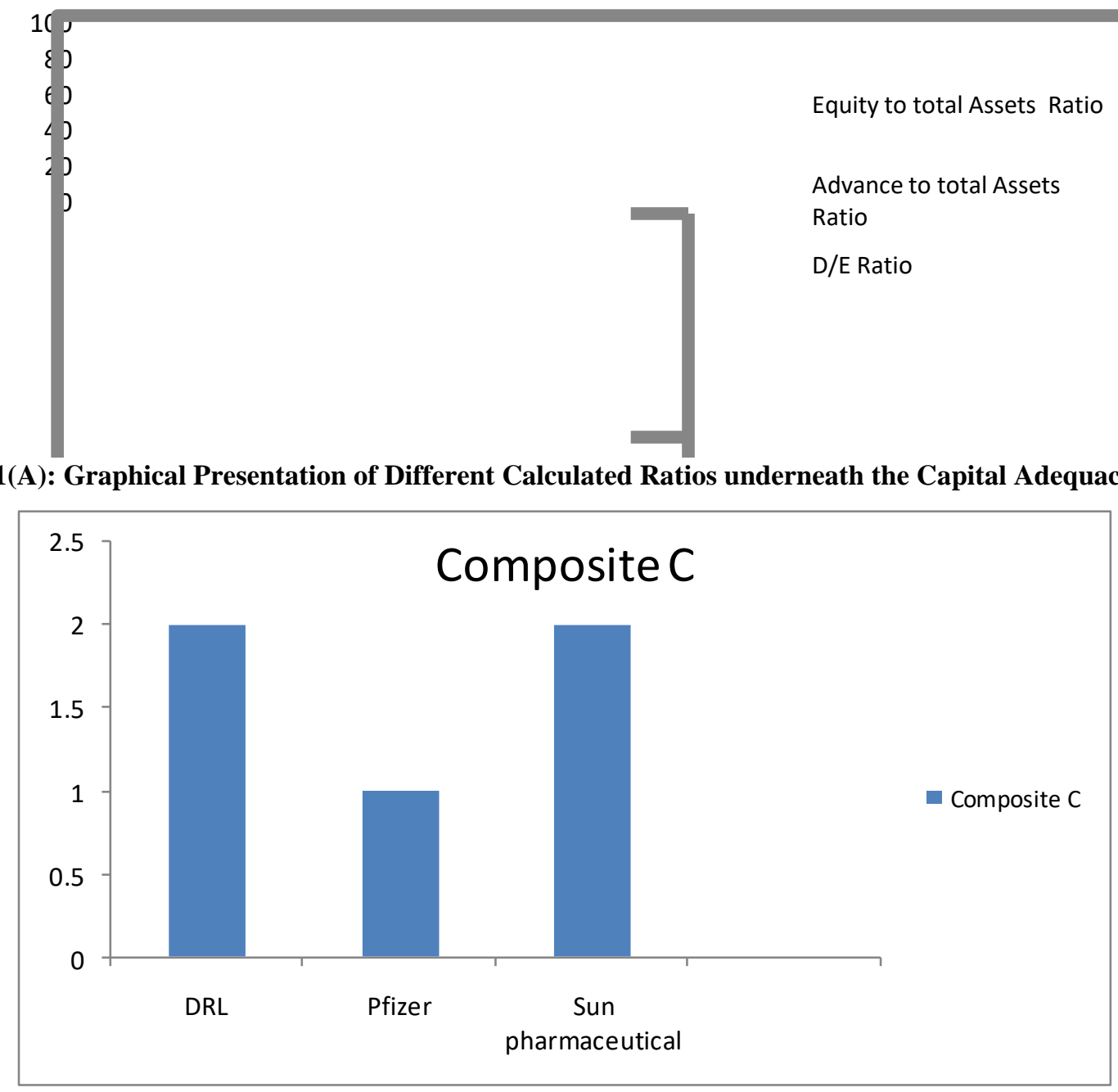

Figure 1(A): Graphical Presentation of Different Calculated Ratios underneath the Capital Adequacy Factor

Figure 2(B): Overall Performance under Capital Adequacy Norm

\section{ANALYSIS}

As per Debt-Equity ratio it has found that Pfizer pharmaceutical industry has ranked 1 with lowest DebtEquity ratio, this industry is using least amount of debt to run the industry, on rank 2 the next industry is DRL and whereas Sun pharmaceutical is using the highest debt, so this industry is on 3 rank. According to Advances to total Assets ratio, Sun pharmaceutical has leaded in lending so, this is on 1 rank. On rank 2 that is Pfizer (2.092) and the last followed by DRL (0.6) with least lending and gets 3 ranks.
In Equity to total Assets ratio Pfizer gets the rank 1 as it has the largest amount of assets for the recovery of its shareholders and rank 2 for DRL and the last followed by Sun pharmaceutical with lowest equity to total assets ratio. As per average rank of above three sub-factors, Pfizer (1.33) ranked number 1, followed by DRL and Sun pharmaceutical, together at rank 2. Only Sun pharmaceutical industry is not doing well in above two sub-factors of capital adequacy out of three, independently as well as combined basis.

Table 2: Different Ratios Underneath Of A- Asset Quality Factor

\begin{tabular}{|l|l|l|l|l|l|l|l|}
\hline Year- & 2015 & 2016 & 2017 & 2018 & 2019 & $\begin{array}{l}\text { Average } \\
\text { Total } \\
\text { Pharmaceutical } \\
\text { Industry Name } \\
\text { to } \\
\text { Assets ratio }\end{array}$ & $\begin{array}{l}\text { Rank } \\
\text { total }\end{array}$ \\
\hline DRL & 20.82 & 23.08 & 18.78 & 12.88 & 13.81 & 17.874 & 1 \\
\hline Pfizer & 0.000098 & 0.000087 & 0.000076 & 0.000000 & 0.000000 & 0.0000522 & 3 \\
\hline $\begin{array}{l}\text { Sun } \\
\text { pharmaceutical }\end{array}$ & 0.47 & 0.37 & 0.43 & 0.36 & 0.83 & 0.492 & 2 \\
\hline
\end{tabular}




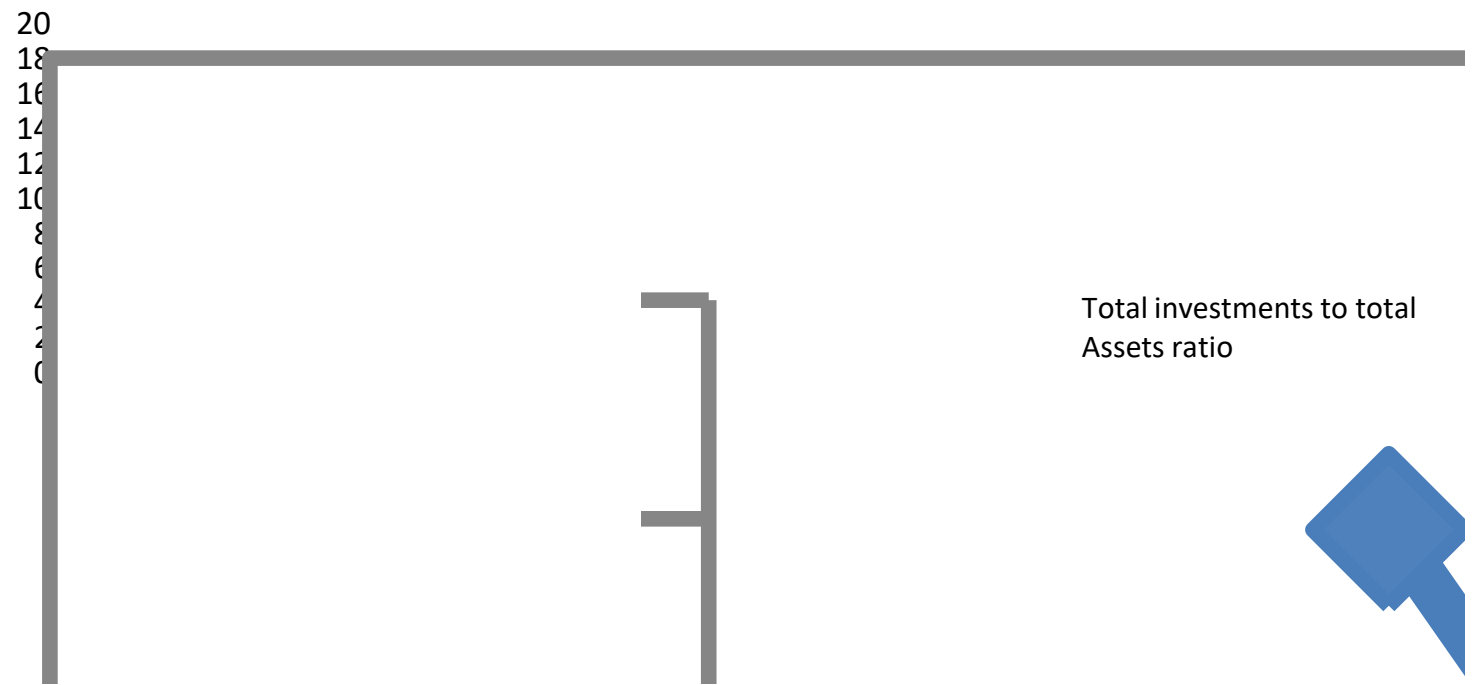

Figure 2(A) Graphical Presentation Of Different Calculated Ratios Underneath The Asset Quality Factor

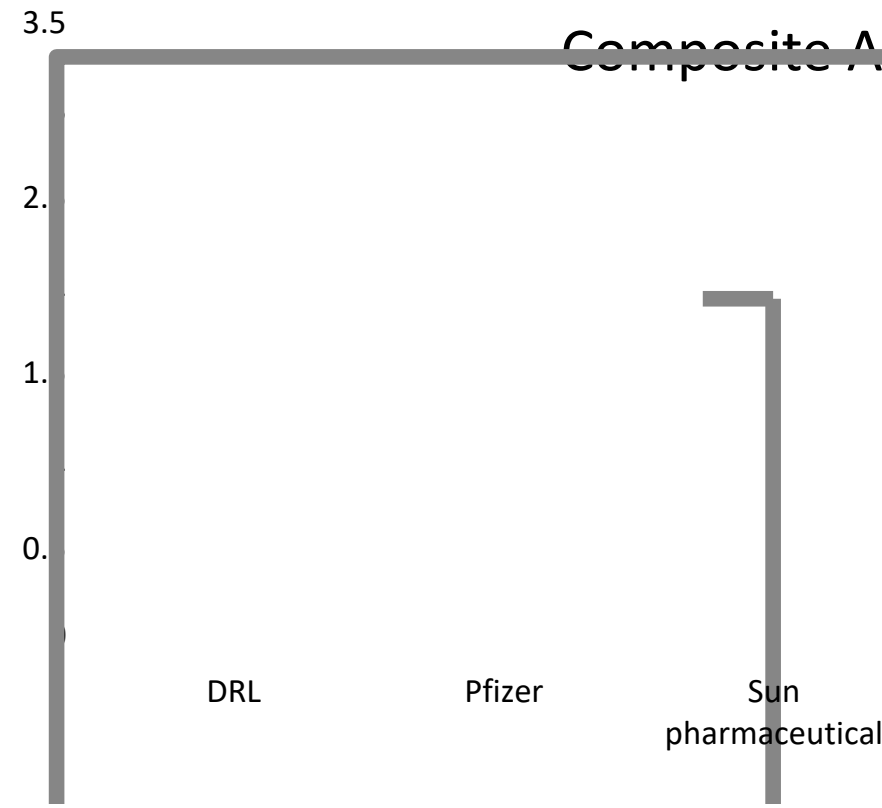

Figure 2 (B): Overall Performance Under Asset Quality Norm

Interpretation: By the help of Total Earning assets to Total Assets ratio, it has found that DRL pharmaceutical industry has ranked 1 with highest investments to total assets ratio. The next is Sun pharmaceutical with ranked 2 and the least is Pfizer with 3 ranked. As per the given ratio Pfizer is not doing well.

Table 3: Different Ratios Underneath Of MManagement Efficiency Factor

\begin{tabular}{|l|l|l|l|l|l|l|}
\hline $\begin{array}{l}\text { Pharmaceut } \\
\text { ical } \\
\begin{array}{l}\text { Industry } \\
\text { Name }\end{array}\end{array}$ & $\begin{array}{l}\text { Average } \\
\text { \& Rank } \\
\text { to ROA }\end{array}$ & $\begin{array}{l}\text { Average } \\
\text { \& Rank } \\
\text { to ROE }\end{array}$ & $\begin{array}{l}\text { Avera } \\
\text { ge } \\
\text { Group }\end{array}$ & $\begin{array}{l}\text { Gro } \\
\text { up } \\
\text { Ran } \\
\mathrm{k}\end{array}$ \\
\hline DRL & $\begin{array}{l}3.19 \\
68\end{array}$ & 2 & $\begin{array}{l}24.3 \\
94\end{array}$ & 1 & 1.5 & 1 \\
\hline Pfizer & $\begin{array}{l}7.90 \\
6\end{array}$ & 1 & $\begin{array}{l}11.4 \\
22\end{array}$ & 2 & 1.5 & 1 \\
\hline $\begin{array}{l}\text { Sun } \\
\text { pharmaceut } \\
\text { ical }\end{array}$ & 8 & 3 & $\begin{array}{l}2.74 \\
8\end{array}$ & 3 & 3.0 & 2 \\
\hline
\end{tabular}




\section{Camel Research of Selected Pharmaceutical Industries}

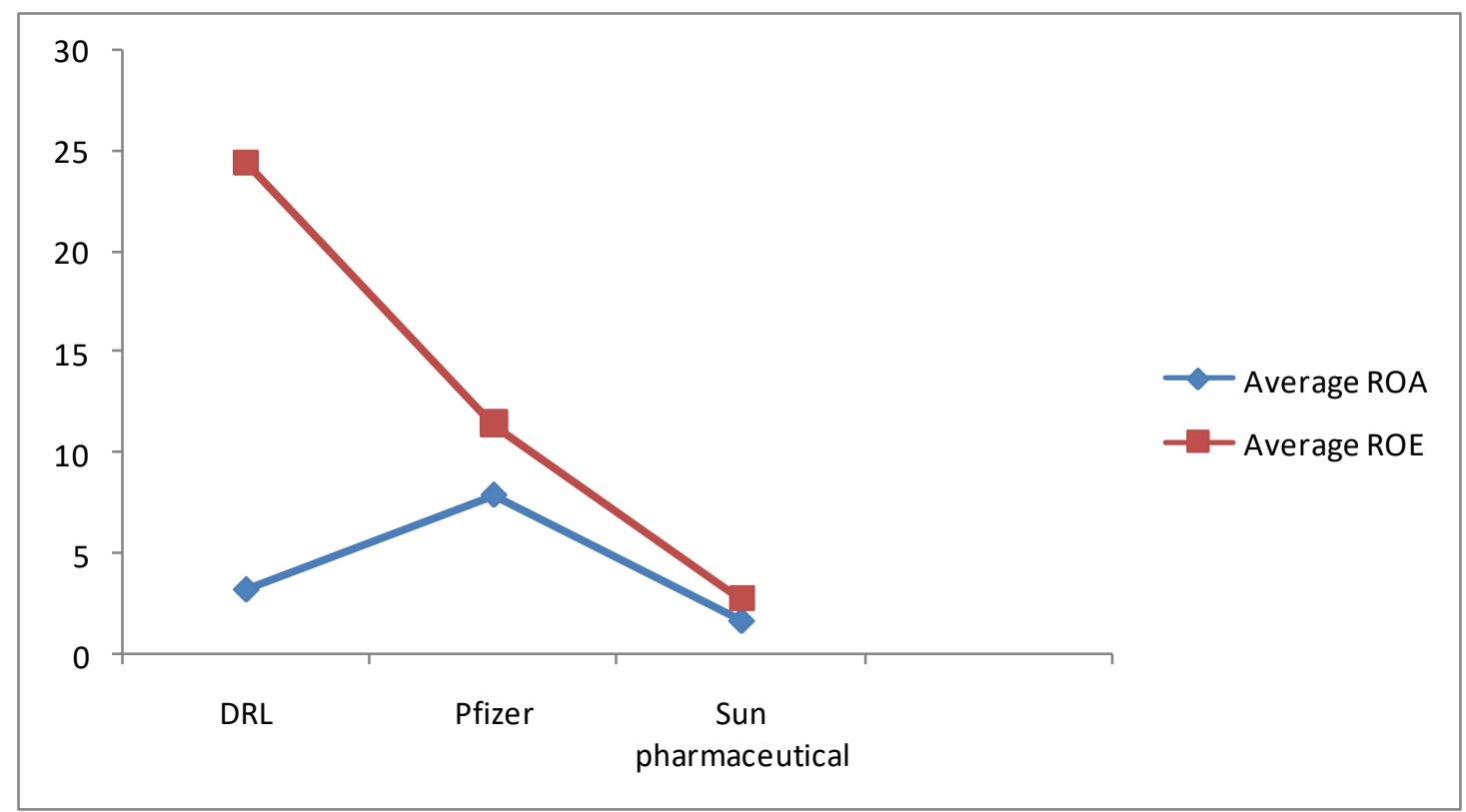

Figure 3 (A): Graphical Presentation Of Different Calculated Ratios Underneath Management Efficiency Factor

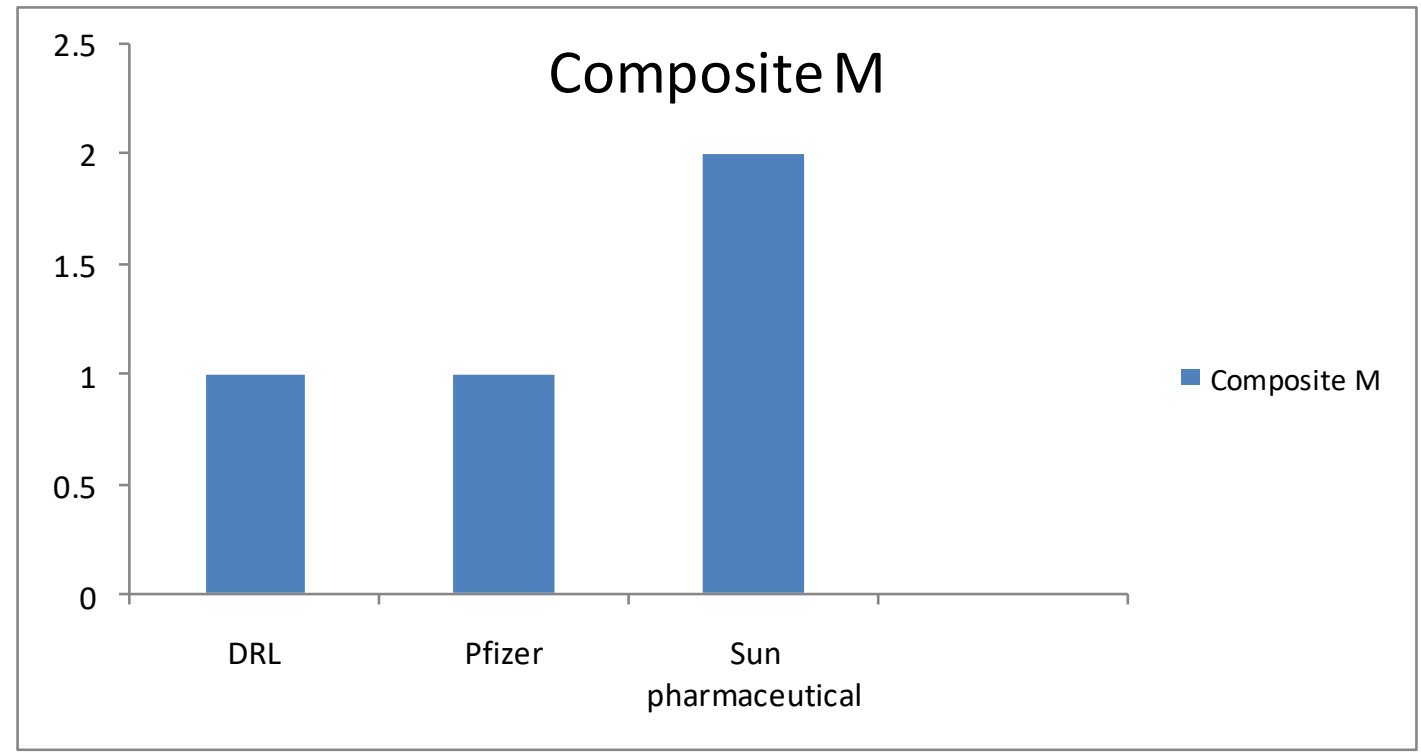

Figure 3 (B) Overall Performances under Management Efficiency Norm

Interpretation: As per above table it is found that Pfizer has ranked 1 in return on assets is the highest one. Next is DRL and again next is Sun pharmaceutical. As per Return on Equity, it is found that DRL is the highest ratio with rank 1. Following is Pfizer and the least ratio industry is Sun pharmaceutical. On the basis of average rank of above two sub-factors DRL and Pfizer have got the same rank as 1 and Sun pharmaceutical has the least rank. So, as per based on the average of two ratios Sun pharmaceutical is not doing so well.

Table 4: Different Ratios Underneath Of E: Earning Quality Factor

\begin{tabular}{|l|l|l|l|l|l|l|l|}
\hline $\begin{array}{l}\text { Year- } \\
\text { Pharmaceutical } \\
\text { Industry Name }\end{array}$ & 2015 & 2016 & 2017 & 2018 & 2019 & $\begin{array}{l}\text { Average } \\
\text { Return on } \\
\text { Invested } \\
\text { Capital }\end{array}$ & $\begin{array}{l}\text { Rank } \\
\text { DRL }\end{array}$ \\
\hline Pfizer & 23.02 & 25.46 & 24.08 & 21.65 & 22.36 & 23.314 & 1 \\
\hline Sun pharmaceutical & -3.42 & -1.72 & 5.72 & 2.31 & 10.12 & 2.602 & 3 \\
\hline
\end{tabular}




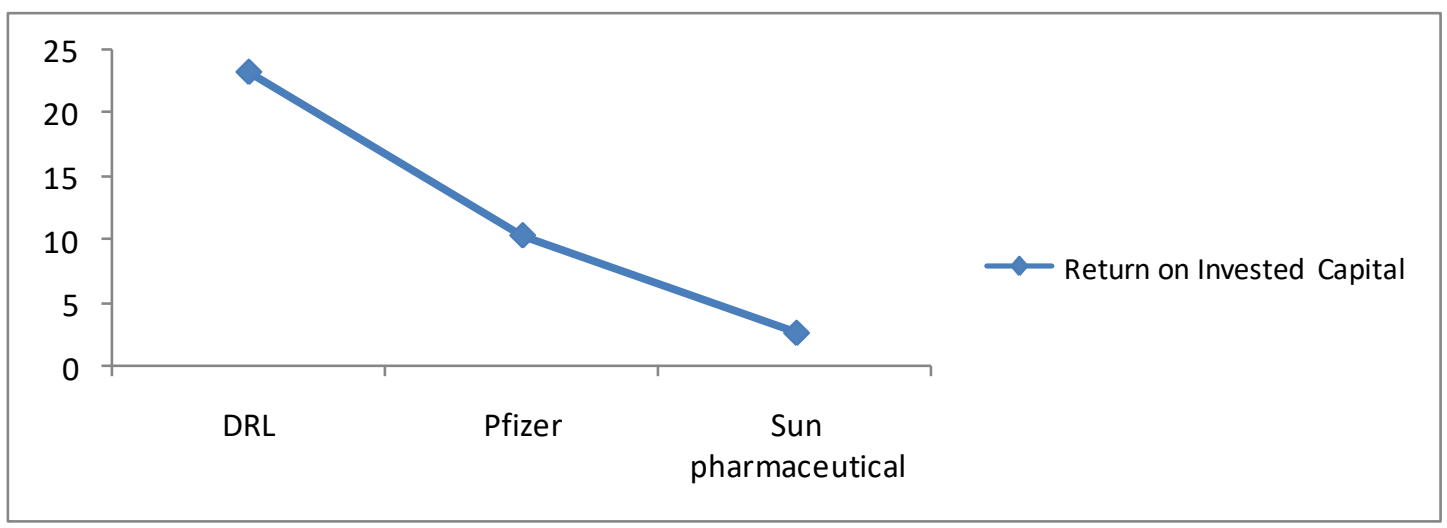

Figure 4(A): Graphical Presentation Of Different Calculated Ratios Underneath Earning Quality Factor

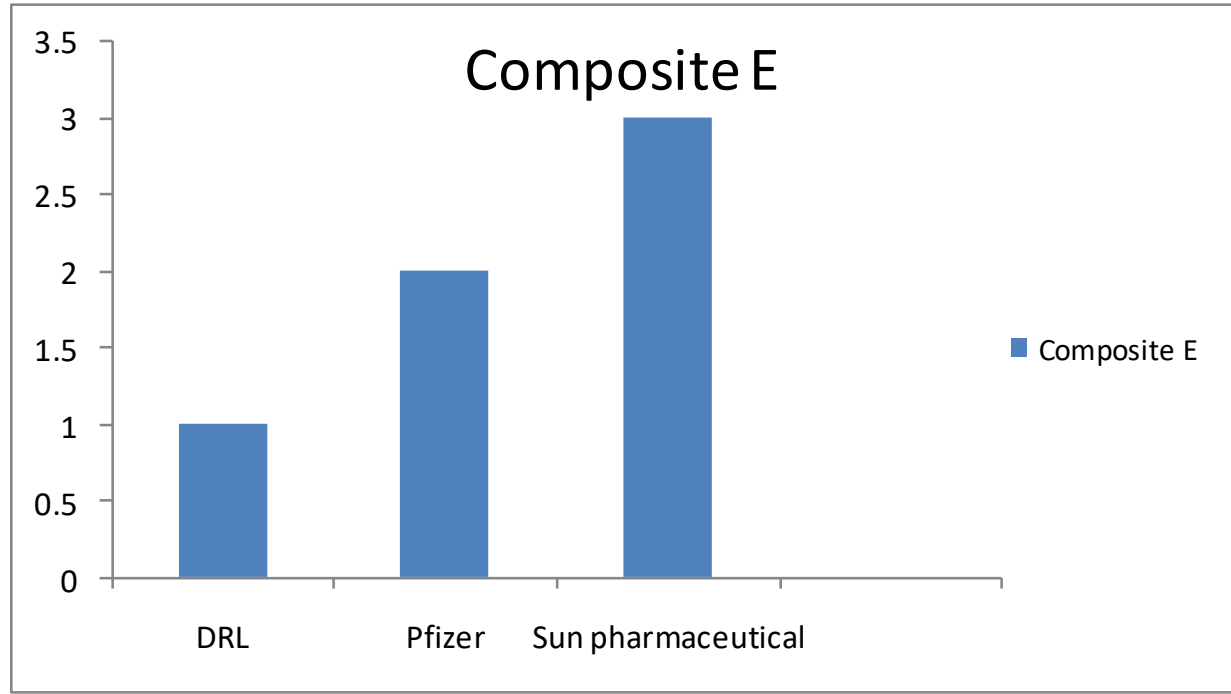

Figure 4 (B) Overall Performances Under Earning Quality Norm

Interpretation: This table shows that DRL is the highest rank 1 in Return on Invested Capital. It means that DRL returns or earning on Invested capital is the highest. Pfizer is on 2 ranks and Sun pharmaceutical is on least rank that is 3. As per this table Sun pharmaceutical has least return on Invested capital and is not doing so well.

Table 5: Different Ratios Underneath Of L: Liquidity Position Factor

\begin{tabular}{|c|c|c|c|c|c|c|c|c|c|c|c|c|}
\hline $\begin{array}{l}\text { Pharmaceutical } \\
\text { Industry Name }\end{array}$ & $\begin{array}{l}\text { Averag } \\
\& \quad \text { R } \\
\text { Highly } \\
\text { Assets } \\
\text { Assets }\end{array}$ & & $\begin{array}{l}\text { Avera } \\
\text { Rank } \\
\text { Curren } \\
\text { Ratio }\end{array}$ & $\begin{array}{l}\& \\
\text { to }\end{array}$ & $\begin{array}{l}\text { Avera } \\
\text { \&Ranl } \\
\text { Balanc } \\
\text { bank } \\
\text { RBI } \\
\text { Total } \\
\text { Assets }\end{array}$ & & $\begin{array}{l}\text { Aver } \\
\& \text { Ra } \\
\text { Cash }\end{array}$ & & $\begin{array}{l}\text { Average } \\
\text { \&Rank } \\
\text { Days Ca } \\
\text { Hand }\end{array}$ & & $\begin{array}{l}\text { Average } \\
\text { Group }\end{array}$ & $\begin{array}{l}\text { Group } \\
\text { Rank }\end{array}$ \\
\hline DRL & 32.466 & 2 & 1.686 & 2 & 2.8 & 2 & 11.8 & 2 & 11.794 & 2 & 2 & 2 \\
\hline Pfizer & 49.652 & 1 & 2.604 & 1 & 5.804 & 1 & 156 & 1 & 297.504 & 1 & 1 & 1 \\
\hline $\begin{array}{l}\text { Sun } \\
\text { pharmaceutical }\end{array}$ & 14.48 & 3 & 0.666 & 3 & .504 & 3 & 2.00 & 3 & 10.452 & 3 & 3 & 3 \\
\hline
\end{tabular}




\section{Camel Research of Selected Pharmaceutical Industries}

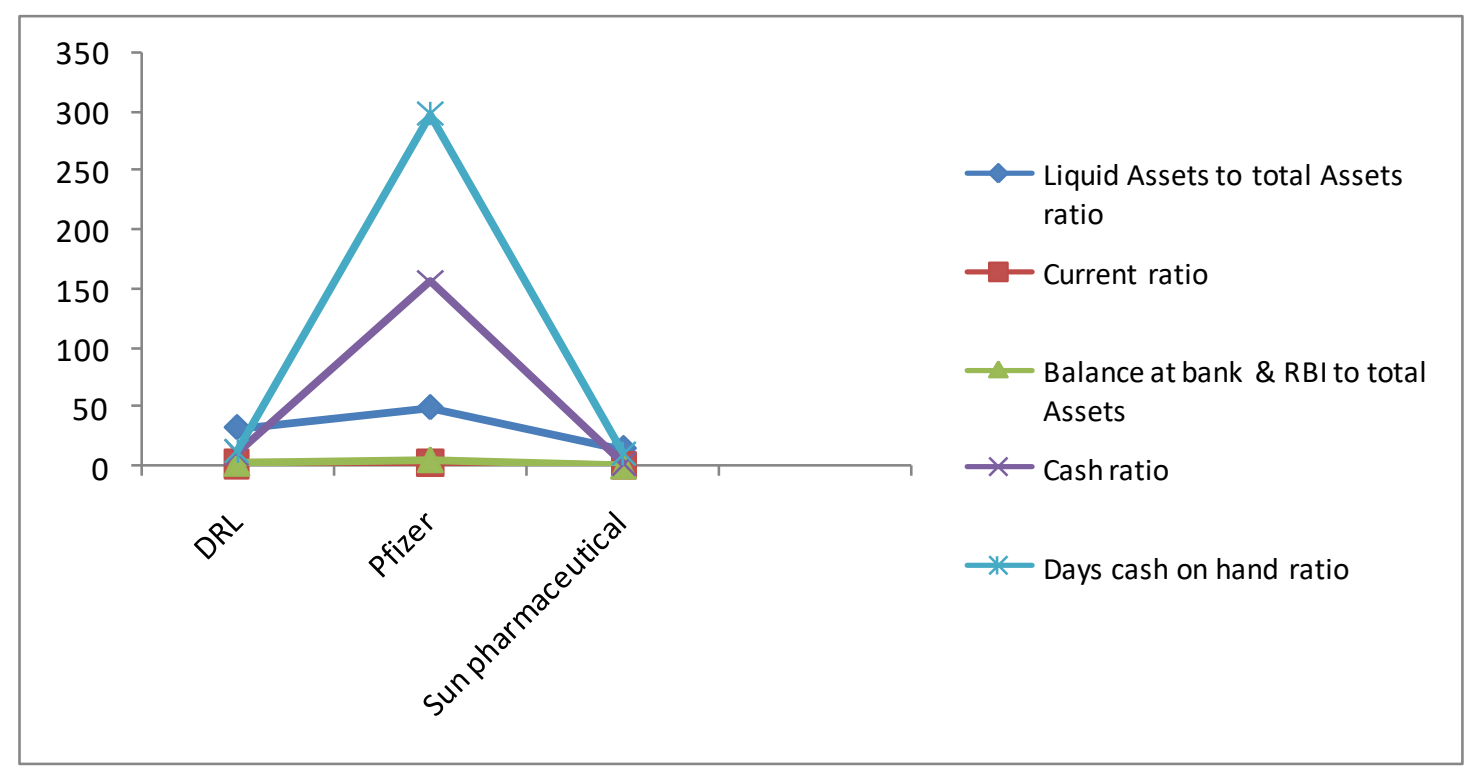

Figure 5(A): Graphical Presentation Of Different Calculated Ratios Underneath Liquidity Position Factor

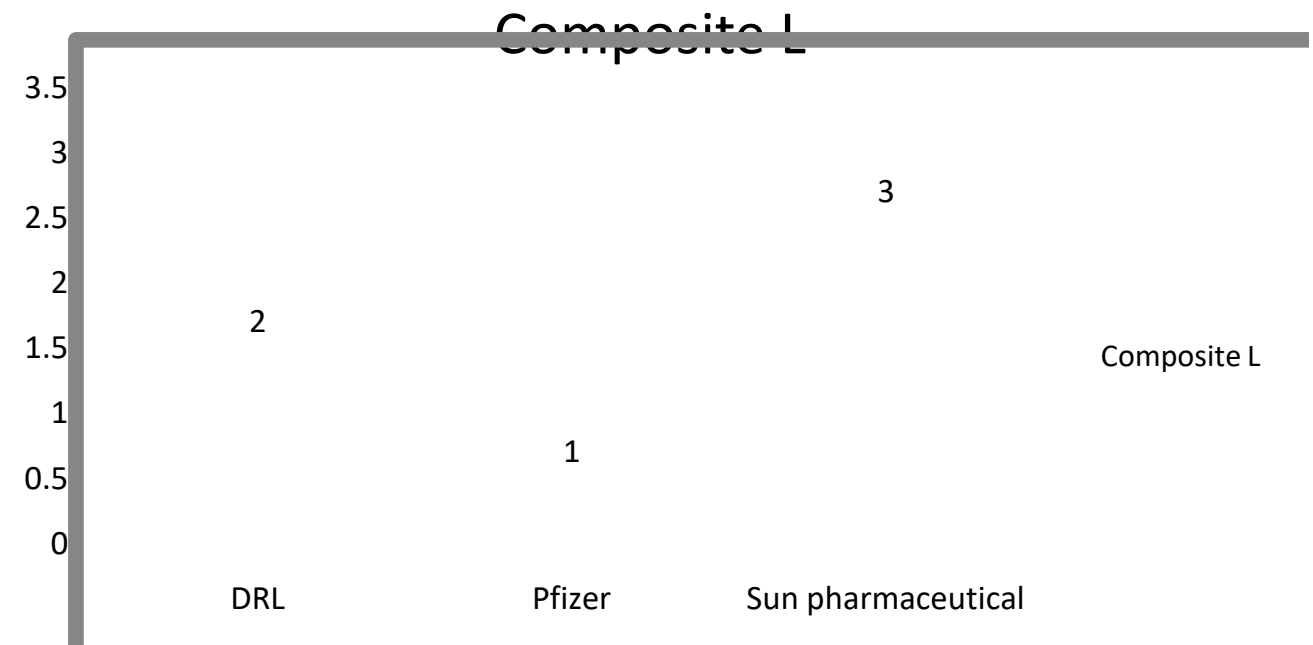

Figure 5 (B): Overall Performance Under Liquidity Position Norm

Interpretation: As per highly liquidity assets to total assets ratio this is shown that Pfizer has the highest liquid Assets to total assets ratio so it get as rank 1 , following industry is DRL and the least one is Sun pharmaceutical. As per current ratio Pfizer has ranked 1 with highest ratio, following industry is DRL and the least one is Sun pharmaceutical. As per Balance at bank \& RBI to total assets ratio Pfizer has ranked 1 with highest ratio, following industry is DRL and the least one is Sun pharmaceutical. It has found that Pfizer gets as 1 rank in cash ratio, following is DRL on 2 ranks and Sun pharmaceutical is on 3 ranks. As per Days cash on hand ratio Pfizer has ranked 1 with highest ratio, following industry is DRL and the least one is Sun pharmaceutical. On the basis of average rank of above five sub-factors, Pfizer ranked 1, DRL on 2 and the least rank 3 is with Sun pharmaceutical. As per overall conclusion of this table Sun pharmaceutical is not doing well as compared to other pharmaceutical industries individually as well as composite basis.

Table 6: Composite Ranking (Overall Performance): Composite Performance (Overall Ranking) Of The Pharmaceutical Industries

\begin{tabular}{|c|c|c|c|c|c|c|c|}
\hline $\begin{array}{l}\text { Pharmaceutical } \\
\text { Industry Name }\end{array}$ & $\begin{array}{l}\text { C(Capital } \\
\text { Adequacy) }\end{array}$ & $\begin{array}{l}\text { A(Assets } \\
\text { Quality) }\end{array}$ & $\begin{array}{l}\text { M } \\
\text { (Management } \\
\text { Efficiency) }\end{array}$ & $\mathrm{E}$ (Earnings) & L(Liquidity) & $\begin{array}{l}\text { Average } \\
\text { of } \\
\text { CAMEL }\end{array}$ & Rank \\
\hline DRL & 2.33 & 17.874 & 1.5 & 23.314 & 2 & 9.4036 & 3 \\
\hline Pfizer & 1.33 & 0.0000522 & 1.5 & 10.344 & 1 & 2.8348 & 2 \\
\hline $\begin{array}{l}\text { Sun } \\
\text { pharmaceutical }\end{array}$ & 2.33 & 0.492 & 3.0 & 2.602 & 3 & 2.2848 & 1 \\
\hline
\end{tabular}




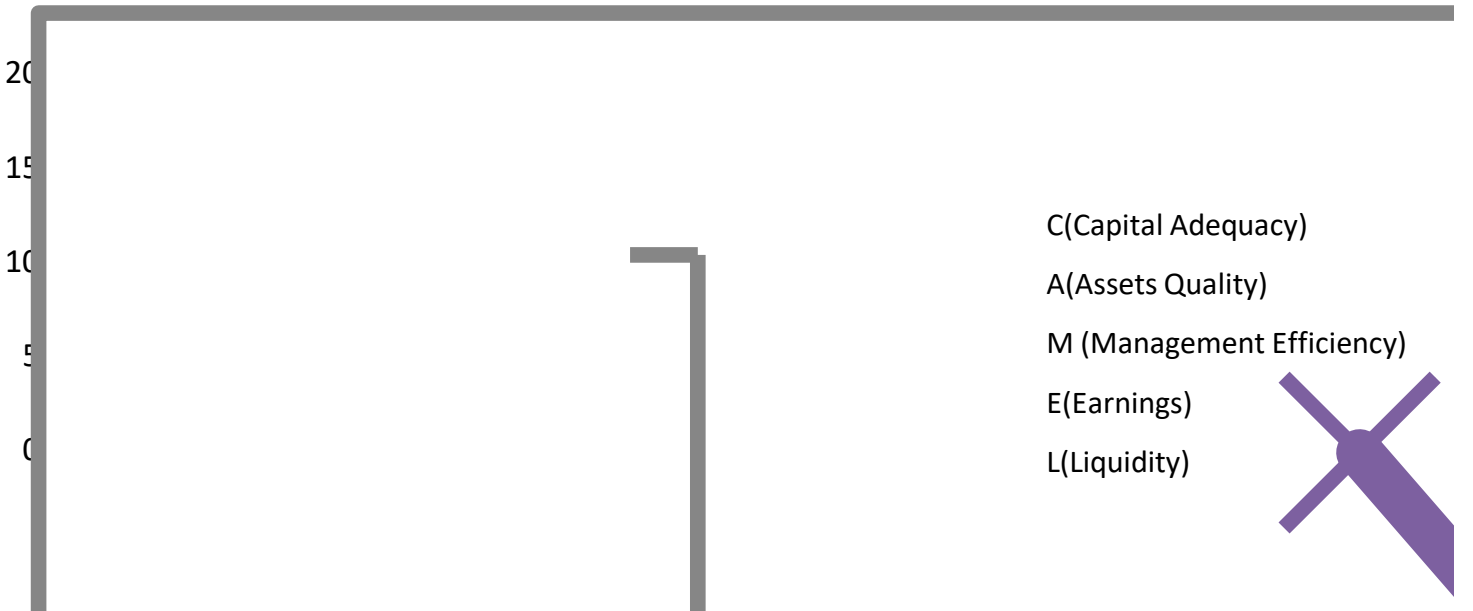

Figure 6(A): Graphical Presentation Of All Factors For The Pharmaceutical Industries Under The Camel Model

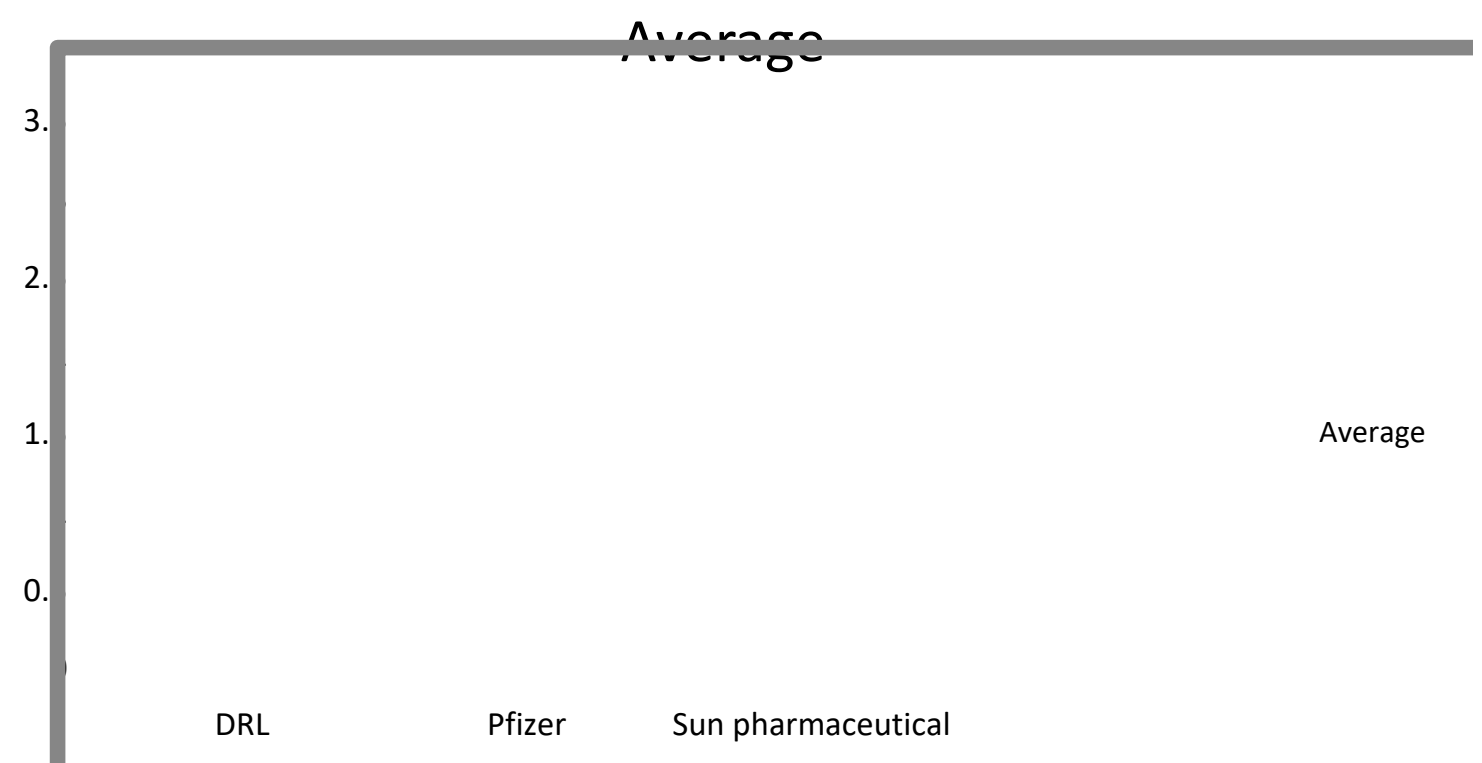

Figure 6 (b): Overall performance combining all the FACTORS

Interpretation: On the basis of CAMEL Analysis combined ranking of all selected pharmaceutical industries from 201415 to $2019-20$ is shown in this table. On performance analysis based, the above table depicts that Sun pharmaceutical is on first place, Pfizer is on second place and DRL is on least rank that is three. So, Sun pharmaceutical is on above average status, Pfizer is on average status and DRL is on below average status.

\section{CONCLUSION}

The present study is based on CAMEL model. In this model there are various factors and sub- factors are used in the form of ratios. After the analytical study it has been concluded that all the factors and sub-factors in Sun pharmaceutical industry is found to be the best performer as compared to other two. Pfizer is on second ranked and DRL is on third on the basis of various factors and sub factors of this model.

\section{REFERENCES}

1. Kumar S., Anjum B., and Nayyar S., (2012). Financing decisions: A study of pharmaceutical companies of India, International Journal of Marketing, Financial Services \& Management Research, 1(1), 14-28.

2. Joseph G. \& John A. Vernon. (2009). Financial risk of the Biotech Industry versus the Pharmaceutical Industry, Applied Health Economics and Health Policy, 7, 155-165.

3. Licurse A., Barber E., Steve J., Cary G. (2010). The Impact of Disclosing Financial Ties in Research and Clinical Care A Systematic Review, Health Care Reform, 170(8), 675-82.

4. David M. Studdert M. Mello M., Troyen A. B. (2004).Financial Conflicts of Interest in Physicians' Relationships with the Pharmaceutical Industry, Self-Regulation in the Shadow of Federal Prosecution, Legal Issues in Medicine, 351, 1891-1900.

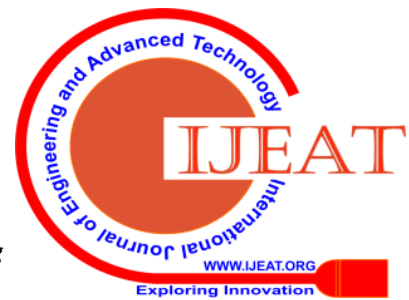




\section{Camel Research of Selected Pharmaceutical Industries}

5. Bharathi K.,G.(2008). Intellectual capital and corporate performance in Indian pharmaceutical industry, Journal of Intellectual Capital, 9(4), 684-704.

6. Pal, K. and Soriya, S. (2012), IC performance of Indian pharmaceutical and textile industry, Journal of Intellectual Capital, 13 (1), 120-137.

7. Garg, K. (2015). An empirical analysis of profitability position of selected private sector banks in India. Journal of Management Sciences and Technology, 2 (3), 22-28.

8. Singh, A. K. (2015). An analysis of profitability position of private banks in India. International Journal of Scientific and Research Publications , 5 (5), 1-11

9. Srinivasan, S. (2016). A Camel model analysis of Public,Private and Foreign Sector Banks in India. Pacific Business Review International, $8(9), 45-57$.

10. Mishra S.K. and Aspal P.K (2013). A Camel Model Analysis of State Bank Group, World Journal of Social Sciences, 3(4), 36-55.

11. Bansal R. and Mohanty A. (2013). A Study on Financial Performance of Commercial Banks in India: Application of Camel Model, AlBarkaat Journal of Finance and Management, 5, 60-79.

12. Gupta R. (2014). An Analysis of Indian Public Sector Banks Using Camel Approach, IOSR Journal of Business and Management (IOSR$J B M), 16(1), 94-102$.

13. Kaur J., Kaur M. and Singh S. (2015). Financial performance analysis of selected public sector banks: A CAMEL model approach, I J A B E R, 13(6), 4327-4348

14. Kaur J., Kaur H. V. (2016). Camel analysis of selected public sector banks, National Conference on Management, Information Technology and Engineering (GJ-NatConMITE 2016) GIAN JYOTI E-JOURNAL, 6(3), 178-189.

15. Meena G. L. (2016). Financial Analysis of Select Banks Using Came Approach a Study with Reference to Indian Banking Industry, International Journal of Research and Scientific Innovation, 3(10), 30-35.

16. Muralidhara P., Lingam C. (2017). Camel Model as an Effective Measure of Financial Performance of Nationalised Banks, International Journal of Pure and Applied Mathematics, 117(7), 255262.

17. Panboli S., Birda K. (2019). Camel Research of Selected Private and Public Sector Banks in India, International Journal of Innovative Technology and Exploring Engineering, 8(12), 25-35.

18. Kiran K. (2018). A CAMEL Model Analysis of Selected Public and Private Sector Banks in India, International Journal of Management, IT \& Engineering, 8 ( 8), 125-132.

19. Kumar V. and Malhotra B. (2017). A Camel Model Analysis Of Private Banks In India, EPRA International Journal of Economic and Business Review, 5(7), 80-89.

20. Zafar, S.M, Adeel M., and Ali N. (2012). A study of ten Indian commercial bank's financial performance using CAMELS methodology, IMS Manthan, 7(1), 1-14.

21. Pati K., kumar A. and Murty, A. V. N. (2017). Financial Performance of Selected Public and Private Sector Banks Based on CAMEL Model with Reference to Indian Banking Sector, International Journal in Management and Social Science, 5(4), 23-29.

22. Balaji C. H., Kumar P. (2017). Performance evaluation of selected public \& private sector banks in India: an application of camel modell, International Journal of Research in IT and Management, 7(3), 62-70.

23. Kaur M. and Priya R. (2017). Evaluating the performance of Public sector Banks-Bank of Baroda and Punjab National Bank: An Application of CAMEL Model with capital and Earning Parameter, Asian Journal of Research in Business Economics and Management, 7(5), 258- 270

24. Waleed A., Shah M. B., Mughal M. K. (2015), Comparison of Private and Public Banks Performance, IOSR Journal of Business and Management, 17( 7)., 32-38.

25. Karthikeyan P., Shangari B. (2014). Calibrating Financial Soundness Among Selected Private Sector Banks In India By Using Camel Model, International Journal Of Management Research And Review, 4(4), 449-454.

26. Biswas M. (2014). Performance Evaluation of Andhra Bank \& Bank Of Maharashtra With Camel Model, International Journal of Business and Administration Research Review, 1(5), 125-131.

27. Suba N. R., Jogi K. P. (2015), Evaluating Performance of Private Sector Banks HDFC \& ICICI: An Application of Camel Model with
Capital \& Earning Parameter, RESEARCH HUB-International Multidisciplinary Research Journal, 2(5), 1-5.

28. Lakhtaria N. J. (2013). A Comparative Study of the Selected Public Sector Banks through Camel Model, Indian Journal of Research, 2( 4), 112-119. 